\title{
Effects of Different Growing Media on Plant Growth and Nutrient Contents of Petunia (Petunia hybrida)
}

\author{
Füsun Gülser ${ }^{(1)}$, Arzu Çı̆̆ ${ }^{(D 2, *}$, Tuğba Hasibe Gökkaya ${ }^{(1)}$, Hayri Atmaca1
}

${ }^{1}$ Department of Soil Science \& Plant Nutrition, Faculty of Agriculture, VanYüzüncü Yıl University, Van, Turkey ${ }^{2}$ Department of Horticulture, Faculty of Agriculture, Siirt University, Siirt, Turkey

\begin{abstract}
The objective of this study was to investigate the effects of different growing media on plant growth and nutrient contents of petunia (Petunia hybrida). The experiment was conducted in a chamber room under controlled conditions at the laboratory. Seven different media (soil, 3:1 soil: peat (P1), 2:1 soil: peat (P2), 3:1 soil: barnyard manure (BYM1), 2:1 soil: barnyard manure (BYM2), 3:1 soil: sugar beet pulp (SBP1), 2:1 soil: sugar beet pulp (SBP2)) were used as plant growing media. The experiment was ended after three months following transplanting of seedlings. Plant growth and flower parameters and macro-micro nutrient contents were determined in harvested plants. The highest stem diameter, branch number, flower diameter, flower stalk diameter, plant fresh weight and plant dry weight were in $2: 1$ ratio of soil: peat mixture as $7.00 \mathrm{~mm}, 6.33,8.91 \mathrm{~cm}, 3.59$ $\mathrm{mm}, 48.47 \mathrm{~g}$ and $4.52 \mathrm{~g}$ while the highest plant lenght, lateral branch number and flower number means were found as $27.43 \mathrm{~cm}, 24.67$ and 24.67 in ratio of 3:1 soil: peat growing media respectively. The highest potassium, magnesium and zinc means of plants were obtained as $6.6 \%, 2.2 \%$ and $32.50 \mathrm{mg} \mathrm{kg}^{-1}$ in soil: barnyard manure $(2: 1)$ growing media while the highest phosphorus and calcium means of plants were found as $0.27 \%$ and $4.5 \%$ in soil and peat growing media respectively. The highest iron and copper means of plants were determined as $231 \mathrm{mg} \mathrm{kg}^{-1}$ and $32.50 \mathrm{mg} \mathrm{kg}^{-1}$ in ratios of $2: 1$ and $3: 1$ of soil: sugarbeet pulp growing media respectively.
\end{abstract}

\section{ARTICLE HISTORY}

Received: April 16, 2109

Revised: July 05, 2019

Accepted: October 17, 2019

\section{KEYWORDS}

Petunia,

Petunia hybrida,

Growing media,

Plant growth,

Nutrient content

\section{INTRODUCTION}

In the last decades ornamental plants are grown for decorative purposes in garden and landscape design projects, as house plant, for cut flowers. The commercial production of ornamental plants is growing and the related market is developing fast. Petunia (Petunia hybrida) belong to the Solanaceae family [1]. Petunias are perennials in warm climates and are used mainly as annual bedding and container plants in temperate regions [2]. Petunias are among the most popular bedding plants in the world because of their adaptability, variety and flower color range. Petunias are quantitative long-day plants flowering under any photoperiod but flowering faster under long days. Short photoperiods (8-10 hours) delay flowering, retard elongation of the main stem and support lateral branching. The average of daily temperature

CONTACT: Arzu Çı̆ $\bowtie$ arzucig@yahoo.com $\Xi$ Department of Horticulture, Faculty of Agriculture, Siirt University, Siirt, Turkey 
degree changes range of in $10-25^{\circ} \mathrm{C}$ for flowering time, plant height and lateral branching [3]. Hybrid petunias are garden standbys from several South American petunia species. These sun and heat-loving annuals or tender perennials were among the first ornamentals grown in the bedding plant market since the 1950's. Petunia cultivated in flower beds and pots requires full sunlight to produce plants and flowers with bright attractive colors. They need abundant sun and grow best in rich soil with good drainage. They bloom best with regular fertilization and will continue to flower all seasons [4].

Increased flower production, quality of flower and perfection in the form of plants are recognised as important issues in bedding and flower production. According to Boodley [5], quality of flowers are considered as function of nutrient level. Nitrogen, phosphorus and potassium enormously influence the production and quality of flowers. Whereas using of synthetic fertilizers and chemicals in flower breeding increase cost of production. In addition these materials can lead environmental pollution problem with potantial hazards to flora, fauna and human.

Under this circumstances, using of organic manures such as compost, vermicompost, barnyard manures and biofertilizers is ecofriendly, easily avaliable and cost effective. It is reported that organic materials provide nutrient conversion of organic fertilizer and mineral fertilizer combination, protection of soil moisture, increasing of cation exchange capacity, improving soil physical and biological properties and providing control of erosion [6-10]. Among the organic materials peat often enchances aeration and water retention [11]. Ko et al. [12] reported that cattle manure compost can be used as a source of soil amendment and organic matter in agriculture which improves the quality of the crop and the environment.

The aim of this study was determine the effects of peat, barnyard manure and sugar beet pulp applications on growth and flowering parameters and nutrient contents of petunia.

\section{MATERIAL and METHODS}

This experiment was conducted in a randomized experimental design with three replication in a chamber room under controlled conditions at Department of Soil Science and Plant Nutrient Laboratory. Petunia (Petunia hybrida) were used as experiment plant in this study. Seven different media (soil, 3:1 soil: peat (P1), 2:1 soil: peat (P2), 3:1 soil: barnyard manure (BYM1), 2:1 soil: barnyard manure (BYM2), 3:1 soil: sugar beet pulp (SBP1), 2:1 soil: sugar beet pulp (SBP2)) were used as plant growing media. Soil and organic materials were mixed according to volume basis. The experiment was ended after three months following transplanting of seedlings. Plant length, steam diameter, branch number, lateral branch number, flower number, flower diameter, flower stalk diameter, plant fresh weight, plant dry weight and macro-micro nutrient contents were measued harvested plants. The nutrient contents of the harvested plant samples were analyzed in dried and grinded plant samples according to following methods reported by Kacar [13]. The P level was analyzed by the spectrophotometric method, and $\mathrm{K}, \mathrm{Ca}, \mathrm{Mg}, \mathrm{Fe}, \mathrm{Mn}, \mathrm{Zn}$, and $\mathrm{Cu}$ levels were determined by using an atomic absorption spectrophotometer (Thermo ICE 3000 series). Soil properties and some properties of growing medias were determined using the standart analyses methods [14]. Physical and chemical properties of the growth media had loamy texture, non saline, slightly alkaline, low in organic matter, insufficient in phosphorus and zinc contents sufficient in calcium, magnesium, manganese and copper contents (Table 1).

Table 1. Properties of the experiment soil

\begin{tabular}{|c|c|c|c|c|c|c|c|c|c|c|c|c|}
\hline \multirow[t]{2}{*}{ Texture } & \multirow[t]{2}{*}{$\mathrm{pH}$} & Salinity & Lime & $\mathrm{OM}$ & $\mathrm{P}$ & $\mathrm{K}$ & $\mathrm{Ca}$ & $\mathrm{Mg}$ & $\mathrm{Fe}$ & $\mathrm{Mn}$ & $\mathrm{Zn}$ & $\mathrm{Cu}$ \\
\hline & & $\left(\mu \mathrm{S} \mathrm{cm}^{-1)}\right.$ & $(\%)$ & $(\%)$ & & \multicolumn{7}{|c|}{$\left(\mathrm{mg} \mathrm{kg}^{-1}\right)$} \\
\hline Loamy & 7.81 & 360.7 & 3.86 & 1.32 & 5.50 & 298 & 3034 & 405 & 5.58 & 29.84 & 0.58 & 0.81 \\
\hline
\end{tabular}


Some properties of the organic materials used in this study were given in Table 2.

Table 2. Some properties of organic materials used in different growth media

\begin{tabular}{llll}
\hline Organic material & $\mathrm{pH}$ & $\mathrm{EC}\left(\mathrm{mS} \mathrm{cm}^{-1}\right)$ & Moisture (\%) \\
\hline Peat & 6.52 & 0.16 & 47.79 \\
Barnyard manure & 8.66 & 8.55 & 6.78 \\
Sugar beet pulp & 4.02 & 0.55 & 89.57 \\
\hline
\end{tabular}

$\mathrm{pH}$ levels of organic materials were determined as close to neutral, alkaline and acide for peat, barnyard manure and sugar beet pulp respectively. When the salinity of organic materials were evaluated barnyard manure was found saline while peat and sugar beet pulp were non saline. Sugar beet pulp had the highest water content according to other organic materials. The lowest water content were determined in barnyard manure. Variance analyses of the experimental data were done by SPSS statistical program [15].

\section{RESULTS and DISCUSSION}

The variance analyses of results and the effects of different growth media on plant growth in petunia are given in Table 3 and 4 respectively. According to the variance analyses different growing media significantly $(\mathrm{p}<0.01)$ influenced all of the plant growth parameters (Table 3 ).

Table 3. Variance analyses of the results for plant growth in petunia

\begin{tabular}{lclllllllll}
\hline V. Source & DF & $\begin{array}{l}\text { Plant } \\
\text { length }\end{array}$ & $\begin{array}{l}\text { Stem } \\
\text { diameter }\end{array}$ & $\begin{array}{l}\text { Branch } \\
\text { number }\end{array}$ & $\begin{array}{l}\text { Lateral } \\
\text { branch } \\
\text { number }\end{array}$ & $\begin{array}{l}\text { Flower } \\
\text { number }\end{array}$ & $\begin{array}{l}\text { Flower } \\
\text { diameter }\end{array}$ & $\begin{array}{l}\text { Flower } \\
\text { stalk } \\
\text { diameter }\end{array}$ & $\begin{array}{l}\text { Plant } \\
\text { fresh } \\
\text { weight }\end{array}$ & $\begin{array}{l}\text { Plant } \\
\text { dry } \\
\text { weight }\end{array}$ \\
\hline Application & 6 & $21.34 * *$ & $6.692 * *$ & $12.77 * *$ & $41.02 * *$ & $27.40 * *$ & $17.88 * *$ & $5.26 * *$ & $74.624 * *$ & $53.31 * *$ \\
\hline
\end{tabular}

**significant at 0.01

When it was noticed that Table 4, the highest means belong plant growth parameters were shown with peat applications. The highest plant length, lateral branch number, flower number were obtained as $27.45 \mathrm{~cm}, 24.67$ and 24.67 in 3:1 ratio of soil: peat mixture (P1) while the highest stem diameter, branch number, flower diameter, flower stalk diameter, plant fresh weight and plant dry weight were in $2: 1$ ratio of soil: peat mixture as $7.00 \mathrm{~mm}, 6.33,8.91 \mathrm{~cm}$, $3.59 \mathrm{~mm}, 48.47 \mathrm{~g}$ and $4.52 \mathrm{~g}$ respectively. Generally plant growth parameters and flower parameters means obtained in barnyard manure and sugar beet pulp applications were lower according to those obtained in control and peat applications (Figure 1 and 2). The lowest means of plant length, stem diameter, lateral branch number, plant fresh weight and plant dry weight were found as $8.33 \mathrm{~cm}, 2.67 \mathrm{~mm}, 2.00,0.93 \mathrm{~g}$ and $0.12 \mathrm{~g}$ in $2: 1$ ratio of soil: barnyard manure mixture (BYM2). In this study the means of plant growth parameters and flower parameter means obtained by different organic metarials exhibit the following decreasing trend: peat>sugar beet pulp>barn yard manure. Generally the decreases in plant growth and flower growth were determined by increasing amounts of barnyard manure and sugar beet pulp in their mixtures by soil. Although increasing amounts of peat in its mixtures by soil increased plant and flower growth, the means of plant and flower growth parameters indifferent peat ratios were in same group according to Duncan's multiple comparison test. The high $\mathrm{pH}$ level and salinity in barnyard manure lead to decreases plant and flower growth. Similarly, sugar beet pulp having low $\mathrm{pH}$ level may have been caused decreasing in plant and flower growth. It was known that soil properties of plant growth media have very importance for nutrient uptake, grow and yield. It was reported that sugar beet pulp and cattle manure addition to soil improve 
soil quality, soil organic matter, soil aggregat stability, water holding capacity and nutrient content (especially N, P and K) [12,16,17].

Table 4. Effects of different growth media on plant growth in petunia

\begin{tabular}{llllllllll}
\hline Application & $\begin{array}{l}\text { Plant } \\
\text { length } \\
(\mathrm{cm})\end{array}$ & $\begin{array}{l}\text { Stem } \\
\text { diameter } \\
(\mathrm{mm})\end{array}$ & $\begin{array}{l}\text { Branch } \\
\text { number }\end{array}$ & $\begin{array}{l}\text { Lateral } \\
\text { branch } \\
\text { number }\end{array}$ & $\begin{array}{l}\text { Flower } \\
\text { number }\end{array}$ & $\begin{array}{l}\text { Flower } \\
\text { diameter } \\
(\mathrm{mm})\end{array}$ & $\begin{array}{l}\text { Flower } \\
\text { stalk } \\
\text { diameter } \\
(\mathrm{mm})\end{array}$ & $\begin{array}{l}\text { Plant } \\
\text { fresh } \\
\text { weight } \\
(\mathrm{g})\end{array}$ & $\begin{array}{l}\text { Plant } \\
\text { dry } \\
\text { weight } \\
(\mathrm{g})\end{array}$ \\
\hline Control & $20.67 \mathrm{~b}$ & $3.17 \mathrm{~b}$ & $1.00 \mathrm{~b}$ & $7.00 \mathrm{~b}$ & $7.00 \mathrm{~b}$ & $6.60 \mathrm{~b}$ & $2.72 \mathrm{bc}$ & $9.03 \mathrm{~b}$ & $0.85 \mathrm{~b}$ \\
P1 & $27.43 \mathrm{a}$ & $6.83 \mathrm{a}$ & $4.67 \mathrm{a}$ & $24.67 \mathrm{a}$ & $24.67 \mathrm{a}$ & $8.83 \mathrm{a}$ & $3.27 \mathrm{ab}$ & $45.10 \mathrm{a}$ & $4.20 \mathrm{a}$ \\
P2 & $26.40 \mathrm{a}$ & $7.00 \mathrm{a}$ & $6.33 \mathrm{a}$ & $23.33 \mathrm{a}$ & $23.00 \mathrm{a}$ & $8.91 \mathrm{a}$ & $3.59 \mathrm{a}$ & $48.47 \mathrm{a}$ & $4.52 \mathrm{a}$ \\
BYM1 & $9.17 \mathrm{~cd}$ & $3.25 \mathrm{~b}$ & $1.00 \mathrm{~b}$ & $3.33 \mathrm{~b}$ & $3.33 \mathrm{~b}$ & $2.83 \mathrm{~d}$ & $2.50 \mathrm{bc}$ & $1.93 \mathrm{~b}$ & $0.26 \mathrm{~b}$ \\
BYM2 & $8.33 \mathrm{~d}$ & $2.67 \mathrm{~b}$ & $1.00 \mathrm{~b}$ & $2.00 \mathrm{~b}$ & $2.50 \mathrm{~b}$ & $3.10 \mathrm{~cd}$ & $2.25 \mathrm{c}$ & $0.93 \mathrm{~b}$ & $0.12 \mathrm{~b}$ \\
SBP1 & $14.50 \mathrm{c}$ & $4.67 \mathrm{~b}$ & $2.67 \mathrm{~b}$ & $6.00 \mathrm{~b}$ & $3.67 \mathrm{~b}$ & $4.78 \mathrm{c}$ & $2.08 \mathrm{c}$ & $4.37 \mathrm{~b}$ & $0.50 \mathrm{~b}$ \\
SBP2 & $10.50 \mathrm{~cd}$ & $3.50 \mathrm{~b}$ & $1.67 \mathrm{~b}$ & $3.67 \mathrm{~b}$ & $3.50 \mathrm{~b}$ & $4.63 \mathrm{~cd}$ & $2.22 \mathrm{c}$ & $2.60 \mathrm{~b}$ & $0.34 \mathrm{~b}$ \\
\hline
\end{tabular}

(P: Peat; BYM: Barnyard manure; SBP: Sugar beet pulp)

Effects of different growth media on plant growth parameters and flower parameters are also given in Figure 1 and 2.

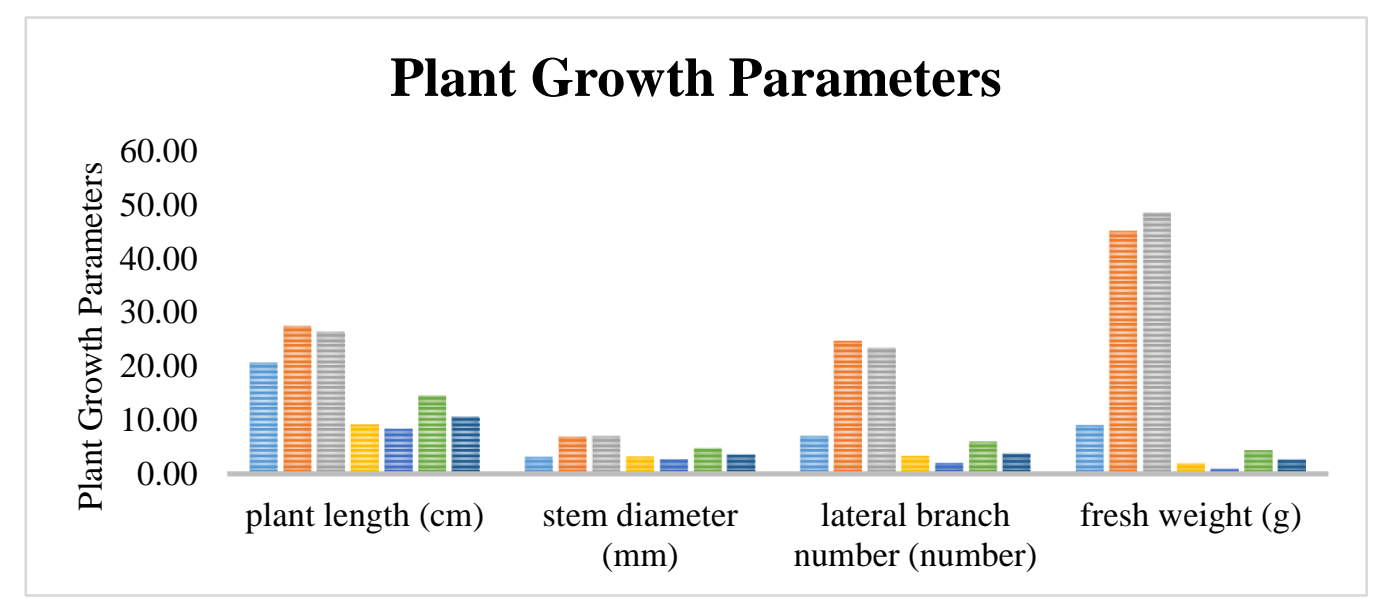

Figure 1. Effects of different growth media on growth parmeters in petunia

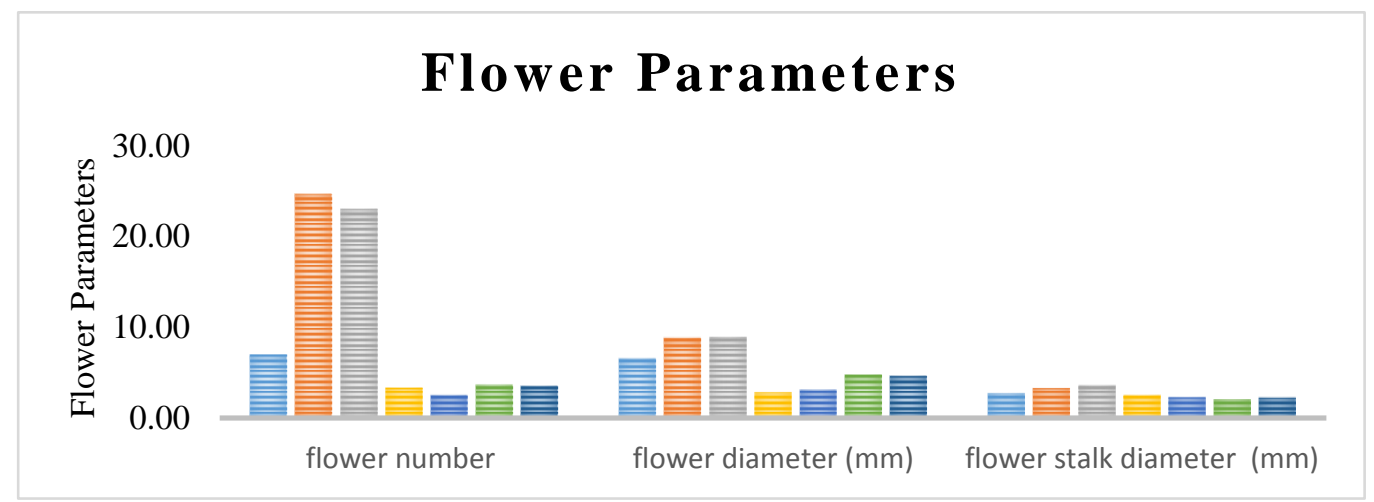

Figure 2. Effects of different growth media on quality parameters in petunia 
Our results were correspond with the referred literature knowledges about sugar beet pulp and cattle manure. Nkongolo et al. [18] and Gülser [19] reported that peat addition to soil improved plant growth in Tagetes. Chamani et al. [20] reported that flower number, leaf length, plant fresh and dry weight increased by vermicompost and peat applications according to control application. Increasing flower production, flower quality and perfection in the forms of plant are the important goals in bedding and flower production. The flower quality was considered as a function of nutrient level [5]. Although nitrogen, phosphorus and potassium considerably influence flower quality and production they lead directly on cost of production. In addition, application of synthetic fertilizers and chemicals in high level lead environmental problem and damage to flora, fauna, and human. In recently, depletion of non renewable resources and environmental deterioration together with their high prices lead utilization of alternative materials as peat, zeolite, perlite animal manure, compost and various organic wastes. In this study, addition of peat to growth media increased plant and flower growth while sugar beet pulp and barnyard manure had non ameliorative effect according to control. It was thought that changes in plant and flower growth in different growth media caused by properties of organic materials. James [21] reported that petunia and begonia can grow in growth media having EC levels in range of 1.7- 6.1 and 2.1- 5.4 $\mathrm{dS} \mathrm{m}^{-1}$ respectively. It was thought that high EC level of baryard manure and low level of sugar beet pulp influenced negatively plant and flower growth of petunia. The variance analyses of results and the effects of different growth media on nutrient contents in petunia are given in Table 5 and 6 respectively.

Table 5. Variance analyses of the results for nutrient contents in petunia

\begin{tabular}{llllllllll}
\hline V. Source & $\mathrm{DF}$ & $\mathrm{P}$ & $\mathrm{K}$ & $\mathrm{Mg}$ & $\mathrm{Ca}$ & $\mathrm{Fe}$ & $\mathrm{Mn}$ & $\mathrm{Zn}$ & $\mathrm{Cu}$ \\
\hline Application & 6 & $6.325^{* *}$ & $38.45^{* *}$ & $6.21^{* *}$ & $8.07^{* *}$ & $6.22^{* *}$ & $7.02^{* *}$ & $14.63^{* * *}$ & $1.80^{* *}$ \\
\hline
\end{tabular}

**significant at 0.01

Table 6. Effects of different growth media on nutrient contents in petunia

\begin{tabular}{lllllllll}
\hline Application & $\begin{array}{l}\mathrm{P} \\
(\%)\end{array}$ & $\begin{array}{l}\mathrm{K} \\
(\%)\end{array}$ & $\begin{array}{l}\mathrm{Ca} \\
(\%)\end{array}$ & $\begin{array}{l}\mathrm{Mg} \\
(\%)\end{array}$ & $\begin{array}{l}\mathrm{Fe} \\
\left(\mathrm{mg} \mathrm{kg}^{-1}\right)\end{array}$ & $\begin{array}{l}\mathrm{Cu} \\
\left(\mathrm{mg} \mathrm{kg}^{-1}\right)\end{array}$ & $\begin{array}{l}\mathrm{Zn} \\
\left(\mathrm{mg} \mathrm{kg}^{-1}\right)\end{array}$ & $\begin{array}{l}\mathrm{Mn} \\
\left(\mathrm{mg} \mathrm{kg}^{-1}\right)\end{array}$ \\
\hline Control & $0.27 \mathrm{a}$ & $4.55 \mathrm{~cd}$ & $4.47 \mathrm{a}$ & $1.90 \mathrm{ab}$ & $174.00 \mathrm{ab}$ & $25.00 \mathrm{a}$ & $28.26 \mathrm{ab}$ & $158.91 \mathrm{bc}$ \\
$\mathrm{P} 1$ & $0.19 \mathrm{c}$ & $4.56 \mathrm{~cd}$ & $4.42 \mathrm{a}$ & $1.41 \mathrm{c}$ & $59.60 \mathrm{c}$ & $17.58 \mathrm{ab}$ & $17.80 \mathrm{c}$ & $135.82 \mathrm{c}$ \\
P2 & $0.20 \mathrm{bc}$ & $4.84 \mathrm{c}$ & $4.47 \mathrm{a}$ & $1.38 \mathrm{c}$ & $44.65 \mathrm{c}$ & $16.79 \mathrm{ab}$ & $18.96 \mathrm{c}$ & $131.30 \mathrm{c}$ \\
BM1 & $0.25 \mathrm{ab}$ & $5.74 \mathrm{~b}$ & $4.42 \mathrm{a}$ & $2.13 \mathrm{a}$ & $113.63 \mathrm{bc}$ & $13.94 \mathrm{~b}$ & $31.28 \mathrm{ab}$ & $163.73 \mathrm{bc}$ \\
BM2 & $0.27 \mathrm{a}$ & $6.63 \mathrm{a}$ & $4.41 \mathrm{a}$ & $2.25 \mathrm{a}$ & $100.19 \mathrm{bc}$ & $17.71 \mathrm{ab}$ & $32.50 \mathrm{a}$ & $140.77 \mathrm{c}$ \\
SBP1 & $0.21 \mathrm{bc}$ & $4.10 \mathrm{de}$ & $3.68 \mathrm{~b}$ & $1.47 \mathrm{bc}$ & $160.57 \mathrm{ab}$ & $32.50 \mathrm{a}$ & $27.37 \mathrm{~b}$ & $181.77 \mathrm{~b}$ \\
SBP2 & $0.17 \mathrm{c}$ & $3.82 \mathrm{e}$ & $3.40 \mathrm{~b}$ & $1.46 \mathrm{bc}$ & $230.78 \mathrm{a}$ & $21.29 \mathrm{ab}$ & $28.31 \mathrm{ab}$ & $232.93 \mathrm{a}$ \\
\hline
\end{tabular}

(P:Peat; BM: Barnyard manure; SBP: Sugarbeet pulp)

According to the variance analyses different growing media significantly $(\mathrm{p}<0.01)$ influenced $\mathrm{P}, \mathrm{K}, \mathrm{Ca}, \mathrm{Mg}, \mathrm{Fe}, \mathrm{Mn}, \mathrm{Zn}$ and $\mathrm{Cu}$ contents. The highest macro nutrient contents means were obtained in $\mathrm{BM}$ growth media except $\mathrm{Ca}$. While the highest micro nutrient contents means in SBP growth media except zinc. The highest $\mathrm{Ca}$ and $\mathrm{Zn}$ contents means were found as $4.47 \%$ and $32.50 \mathrm{mg} \mathrm{kg}^{-1}$ in P2 and BM2 growth media (Figure 3 and 4). In this study obtained nutrient contents were correspond with the nutrient contents reported for the other plants belong Solanaceae family such as tomato, potato, eggplant [22]. When nutrient contents levels were evaluated according to reported limit values for eggplant (Solanum melongena) were not found deficiencies except iron $\left(<50 \mathrm{mg} \mathrm{kg}^{-1}\right)$ and zinc $\left(<20 \mathrm{mg} \mathrm{kg}^{-1}\right)$ contents obtained in P2 and P1 
growth media respectively (Figure 4). The $\mathrm{pH}$ has a major role in the availability of nutrient ions. It was known that Marschner [23] macronutrients and micronutrients are more available at levels of $\geq 7 \mathrm{pH}$ and $\leq 7 \mathrm{pH}$ respectively. Sugar beet pulp has lower $\mathrm{pH}$ level than those in the other materials. So micronutrients contents were obtained in high amounts in this growth media compaire to the other materials.

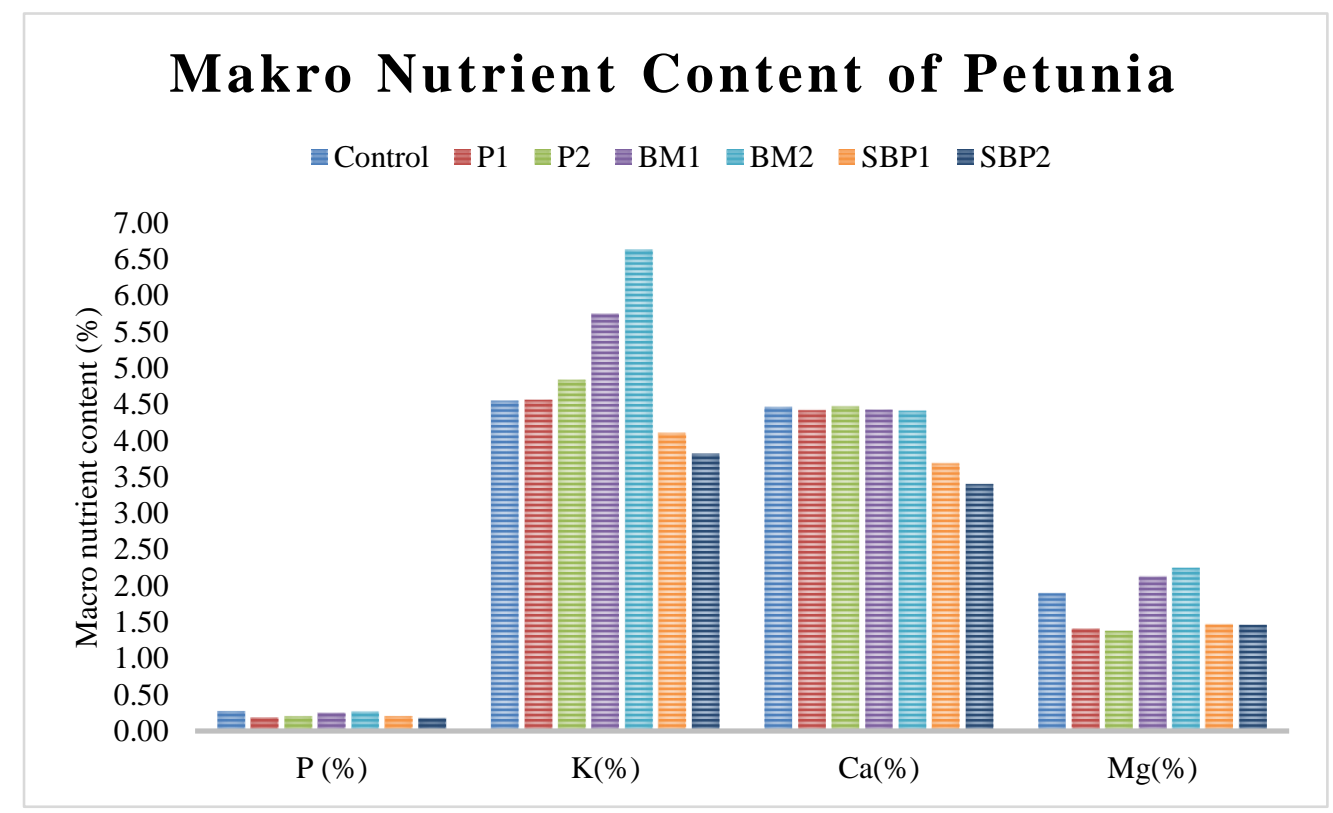

Figure 3. Effects of different growth media on macro nutrient contents in petunia

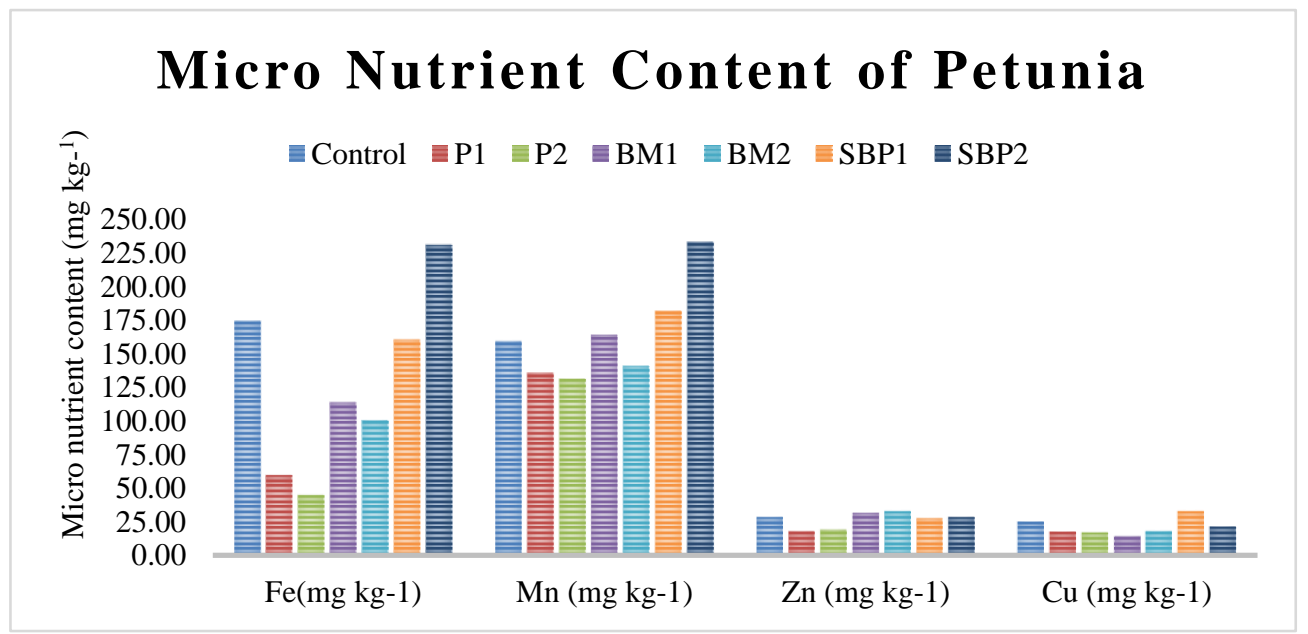

Figure 4. Effects of different growth media on micro nutrient contents in petunia

Our results were correspond with the reffered literature knowledges. [24] reported that addition of sugar beet pulp to soil increased organic matter level. Cattle manure compost addition to soil improve soil quality, soil organic matter, soil aggregat stabilty, water holding capacity and nutrient content (especially N, P and K) [16,17,25]. Raviv et al. [26] reported that peat moss serves as the main component of transplant growth media, mainly due to the following physical and chemical properties: adequate Free Air Space (FAS) at 0-10 cm water suction; high water content at low tension at 10-100 cm water suction; high Cation Exchange Capacity (CEC) which minimizes loss of nutrients and facilitates adequate mineral nutrition. Inbar et al. [27] reported that during last two decades due to improved popularity for protected agriculture, evolution of plant growth techniques has increased demand for container substrates such as peat, zeolite and perlite but supply have been decreasing. Depletion of non 
renewable resources and environmental deterioration with high price of those substrates have favored the utilization of alternative materials as growth substrates [28].

\section{CONCLUSION}

As a result, using of peat can be useful for petunia growth in bedding and flower production. In addition, it can be suggested investigates about separeted mixtures of barnyard manure and sugar beet pulp with soil in different ratios in growth media for petunia breeding. Additionally, it was thought that peat may be beneficial in the stuation of application as combined with barnyard manure and sugar beet pulp for optimum nutrition in petunia.

\section{Acknowledgements}

This study is supported with the project no FHD-2017-6147 by Van Yüzüncü Y1l University Coordinator of Scientific Research and Projects.

\section{Conflicts of Interests}

Authors declare that there is no conflict of interests.

Orcid

Füsun Gülser (D) https://orcid.org/0000-0002-9495-8839

Arzu Çı̆ (D) https://orcid.org/0000-0002-2142-5986

Tuğba Hasibe Gökkaya (DiD https://orcid.org/0000-0001-5956-0764

\section{REFERENCES}

[1]. Paxton, J. (1836). Petunia nyctaginiflora violacea. Paxton's Mag. Bot., 2, 173.

[2]. Baily, L.H., Baily, E.Z. (1976). Petunia. In: Hortus Third: A concise dictionary of plants cultivated in the United States and Canada. Macmillan Publishing, New York, USA, 850851.

[3]. Kessler, R.JR. (1999). Greenhouse Production of Petunias. Southeastern Floriculture, 1519.

[4]. Hoda, E. El-M., Mona, S. (2014). Effect of bio and chemical fertilizers on growth and flowering of Petunia hybrida plants. American Journal of Plant Physiology, 9(2), 68-77. doi:10.3923/ajpp.2014.68.77

[5]. Boodley, J.W. (1975). Plant nutrition and flower crop quality (Dianthus caryophyllus). Horti. Sci., 10(1), 41-48.

[6]. Gülser, C., Pekşen, A. (2003). Using tea waste as a new casing material in mushroom (Agaricus bisporus (L.) Sing.) cultivation. Bioresource Technology, 88(2), 153-156. doi:10.1016/S0960-8524(02)00279-1

[7]. Akça, M.O, Namlı, A. (2015). Effects of poultry litter biochar on soil enzyme activities and tomato, pepper and lettuce plants growth. Eurasian J Soil Sci., 4(3): 161-168. doi:10.18393/ejss.2015.3.161-168

[8]. Demir, Z., Gülser, C. (2015). Effects of rice husk compost application on soil quality par ammeters in greenhouse conditions. Eurasian J Soil Sci., 4(3), 185-190. doi: 0.18393/ejs s.2015.3.185-190

[9]. Gülser, C., Candemir, F., Kanel, Y., Demirkaya, S. (2015). Effect of manure on organic carbon content and fractal dimensions of aggregates. Eurasian J Soil Sci., 4(1), 1-5. doi: $10.18393 /$ ejss. 85620

[10]. Özdemir, N., Öztürk, E., Tebessüm, Ö., Durmuş, K., Ekberli, İ. (2015). Effects of organic and inorganic amendments on soil erodibility. Eurasian J Soil Sci., 4(4), 266-271. doi: 10.18393/ejss.2015.4.266-271 
[11]. Zaller, J.G. (2007). Vermicompost as a substitute for peat in potting media: Effects on germination, biomass allocation, yields and fruit quality of three tomato varieties. Scientia Hortic., 112(2), 191-199. doi: 10.1016/j.scienta.2006.12.023

[12]. Ko, H.J., Kim, K.Y., Kim, H.T., Kim, C.N., Umeda, M. (2008). Evaluation of maturity parameters and heavy metal contents in composts made from animal manure. Waste Manage., 28(5), 813-820. doi: 10.1016/j.wasman.2007.05.010

[13]. Kacar, B. (1984). Bitki Besleme Uygulama Kılavuzu. A.Ü.Z.F.Yay. No:900. Uygulama K1lavuzu: 214, Ankara, 104.

[14]. Kacar, B. (2010). Toprak Analizleri. Genişletilmiş Baskı, XVIII, Nobel yayın Dağıtım. 468.

[15]. SPSS (2018). IBM Corp. Released 2013. IBM SPSS Statistics for Windows, Version 21.0. Armonk, NY: IBM Corp.

[16]. Castrillion, L., Fernandez-Nava Y., Maranon, E., Garcia L., Berrueta, J. (2009). Anoxicaerobic treatment of the liquid fraction of cattle manure. Waste Manage., 29(2), 761-766. doi:10.1016/j.wasman.2008.06.027

[17]. Indraratne, S.P., Hao, X., Chang, C., Godlinski, F. (2009). Rate of soil recovery following termination of long-term cattle manure applications. Geoderma, 150(3-4), 415-423. doi:10.1016/j.geoderma.2009.03.002

[18]. Nkongolo, N.V., Gauthier, F., Caron, J. (2007). Effects of fresh and composted organic waste on media physical properties and growth of three ornamental species. Int. J. of Soil Sci., 2(4), 235-246. doi:10.3923/ijss.2007.235.246

[19]. Gülser, F., Çı̆̆, A., Sönmez, F. (2010). Bazı organik materyallerin kadife çiçeğinde (Tagetes erecta F1 Antigua Orange) bitki gelişimine, çiçeklenme kalitesine ve besin elementi içeriğine etkileri. Ege Üniv. Ziraat Fakültesi Dergisi Özel Sayı, 671-675.

[20]. Chamani, E., Joyce, D.C., Reihanytabar, A. (2008). Vermicompost effects on the growth and flowering of Petunia hybrida 'Dream Neon Rose'. American-Eurasian J. Agric. \& Environ. Sci., 3(3), 506-512.

[21]. James, E.C., Van Iersel, M.W. (2001). Fertilizer concentration affects growth and flowering of subirrigated Petunias and Begonias. HortScience, 36(1), 40-44. doi:10.21273/HORTSCI.36.1.40

[22]. Jones, J.B. Jr., Wolf B., Mills H.A. (1991). Plant Analysis Handbook. Micro- Nacro Publishing INc., Georgia. 30607.USA.

[23]. Marschner, H. (1994). Mineral Nutrition of Higher Plants. London; Academic Press, 889.

[24]. Barik, K. (2011). Ahır gübresi ve pancar küspesi ilavesinin toprağın bazı özelliklerine olan etkisi. J. of Agricultural Faculty of Atatürk Univ., 42(2), 133-138.

[25]. Sager, M. (2007). Trace and nutrient elements in manure, dung and compost samples in Austria. Soil Biol Biochem., 39(6), 1383-1390. doi:10.1016/j.soilbio.2006.12.015

[26]. Raviv, M., Reuveni, R., Zaidman, B.Z. (1998). Improved media for organic trasplants. Biological Agriculture \& Horticulture., $16(1), \quad$ 53-64. doi:10.1080/01448765.1998.9755218

[27]. Inbar, Y., Chen, Y., Hadar, M. (1990). Humic substances formed during the composting of organic matter. Soil Sci. Soc. Am. J., 54(5), 1316-1323. doi:10.2136/sssaj1990.03615995005400050019x

[28]. Abad, M., Noguera, P., Bures, S. (2001). National inventory of organic wastes for use as growing media for ornamental potted plant production: case study in Spain. Bioresour Technol., 77(2), 197-200. 